\title{
Statistical analysis of songs by composers of the Romantic era: A comparison of $F$. Schubert and his contemporaries
}

\author{
iD Linlin Gao \\ Music College, Ningbo University, Ningbo, China \\ 18205089299@163.com \\ He Shen \\ Music College, Ningbo University, Ningbo, China \\ 496859515@qq.com \\ (iD) \\ Chang Liu \\ Music College, Ningbo University, Ningbo, China \\ 615298842@qq.com
}

\begin{abstract}
The study investigates musical compositions via quantification using mathematical methods. The relevance is based on the investigation of Franz Schubert's song cycle Die Winterreise, Robert Schumann's song cycle Myrthen, and on works by other composers. The purpose of the article is statistical analysis of the musical parameters of the songs of these composers. The study obtained p-value estimates for each quantity to assess its adequacy and probability of getting reliable result. The obtained p-values show probability of obtaining corresponding mean value of the investigated parameters. The results revealed that the work of Franz Schubert had longer passages and greater ranges $x 2$, as compared to works by other composers. Besides, he made the use of roots in this work and had more unique and maximum intervals than others. The practical significance of the study is explained by the opportunity to use the results in finding objective criteria for describing his work in comparison with the works of other composers. They also are useful for restoring musical notations, analyzing and classifying works of unknown authorship. The prospects for further research are determined
\end{abstract}


by the use of proposed model for the studying and analyzing the songs of composers not only the Romantic era, but also other periods.

Keywords: Musical technique. P-value. Romantic musical style. Schubert. Statistical analysis.

Resumo: O estudo investiga composições musicais via quantificação usando métodos matemáticos. A relevância baseia-se na investigação do ciclo de canções Die Winterreise de Franz Schubert, no ciclo de canções Myrthen de Robert Schumann e em obras de outros compositores. O objetivo do artigo é a análise estatística dos parâmetros musicais das canções desses compositores. O estudo obteve estimativas de p-valor para cada quantidade para avaliar sua adequação e probabilidade de obter resultado confiável. Os valores de $\mathrm{p}$ obtidos mostram a probabilidade de se obter o valor médio correspondente dos parâmetros investigados. Os resultados revelaram que a obra de Franz Schubert teve passagens mais longas e maiores alcances $x 2$, quando comparada a obras de outros compositores. Além disso, ele fez uso de raízes neste trabalho e teve intervalos mais únicos e máximos do que outros. O significado prático do estudo é explicado pela oportunidade de usar os resultados para encontrar critérios objetivos para descrever sua obra em comparação com as obras de outros compositores. Eles também são úteis para restaurar notações musicais, analisar e classificar obras de autoria desconhecida. As perspectivas de novas pesquisas são determinadas pela utilização do modelo proposto para o estudo e análise das canções de compositores não só da era romântica, mas também de outros períodos.

Palavras-chave: Técnica musical. Valor p. Estilo musical romântico. Schubert. Análise estatística.

Submetido em: 4 de agosto de 2021

Aceito em: 9 de setembro de 2021 
Statistical analysis of songs by composers of the Romantic era: A comparison... Linlin Gao • He Shen • Chang Liu

\section{Introduction}

Classical pieces normally follow a set structure, barring those in the impromptu genre, and are divided into various musical forms. For example, sonata and etude are among the most common forms in instrumental music (NG, 2012), whereas oratorio and cantata are more popular in vocal instrumental music (REYNOLDS, 2013; SMITHER, 2012). Pieces that belong to the impromptu genre originate in improvisation to demonstrate strong finder dexterity skills. In certain sense, musical forms or structures serve as certain frameworks of music compositions, which were well described in the past (GOMEZ et al., 2014; LIU et al., 2010). Although some forms may be similar in terms of tempo and tonality standards, there can be dramatic differences between compositions created during different historical periods. Furthermore, each piece stands out with a special touch added to it by the composer. ${ }^{1}$

During the Baroque era (1600-1750), for example, any form of art had a certain extent of ornamentation and pomp to it. Baroque music is often described as grandiloquent and extraordinary. Classicism (1750-1820), which initially developed in parallel with Baroque to later replace it, introduced standards and strict forms to music. 'Thus, the eternal controversy between artist and critic about the standards of art criticism flamed up in a violent manner and was indicative of all periods of transition,' wrote Manfred and Bukofzer in their book in 2013. During Romanticism (1820-1890), which is often opposed to Classicism, composers did not abandon the past musical forms but made them more sensual and vibrant (DALLA BELLA and PERETZ, 2005). Furthermore, the vocal form, as a way to oppose characters and naturally show their feelings, acquires a special role in the music industry.

Music compositions come in a diverse range of musical forms and mathematics can quantify the piece of music with a fair degree of accuracy. Mathematical methods can serve as a powerful tool

1 To learn more about the Romantic era of music and composers creating at the time, read HONOUR (2018), BURKHOLDER et al. (2019), and CASALIGGI and FERMANIS (2016). 
Statistical analysis of songs by composers of the Romantic era: A comparison... Linlin Gao • He Shen • Chang Liu

in music research. More details about how mathematics relates to music you may find in (EDELSON and JOHNSON, 2003; ROBERTS, 2016). Through the use of computer analysis, music researchers can 'dig' into the core of a music piece (ELAINE et al., 2016), classify it (CORRÊA and AP RODRIGUES, 2016) and identify the style of the composer (RYDÉN, 2020). Statistical methods are among the most common choices and used in multiple applications. The availability of computers and advanced mathematical tools allow scientists to automatically recognize an artist through the use of a sound database. Other vivid examples of mathematical methods being successfully used in the music research were discussed in the resent publications (FOWLER, 2020; POPOFF et al., 2018; REN et al., 2018).

With a technique described below, a range of complex musicrelated and, to some extent, historical problems can be solved. For instance, statistical analysis can help identify notes that are missing if the source (music sheet or record) was damaged or replaced by the composer himself. Today, musicology has to deal with the existence of the two handwritten sketches of the Beethoven's Hammerklavier Sonata, which are non-similar in terms of text (GRIER, 1996). Furthermore, statistical methods help classify compositions by genre, form, and even by the style of the composer.

This study is aimed at exploring the music compositions by Franz Schubert (1797-1828) from the statistical analysis perspective and finding distinctive features. The study deals with statistical data (e.g. mathematical analogies of certain features) that characterize the work of the given and other composers and builds histograms for visualization purposes. In addition, on the basis of the obtained data, it was carried out a comparative analysis of Schubert's and Schumann's works, as well as a group of randomly taken works of various composers of the era of Romanticism. In the course of the study, in addition to the most probable values of the parameters, by means of a comparative analysis, it was revealed that the studied parameters vary quite a lot depending on the studied group. This 
Statistical analysis of songs by composers of the Romantic era: A comparison...

Linlin Gao • He Shen • Chang Liu

fact suggests that the selected parameters can indeed characterize the work of individual composers.

'His [Schubert'] 'Trout' Quintet, his 'Unfinished' Symphony, the three last piano sonatas, and above all his song cycles Die Schöne Müllerin and Winterreise have come to be universally regarded as belonging to the very greatest works of music,' said Elizabeth Norman MCKAY (1998). Nevertheless, despite the enormous contribution of this composer to western music, he is little studied by mathematicians. The math based type of research is mostly concerned with the classical music composers such as Johann Sebastian Bach (1685-1750) and Wolfgang Amadeus Mozart (17561791) (MARTORELL and GÓMEZ, 2015; SHAFER and SULTON, 2010) because of their streamlined and rigorous work.

This is a comparative study of Schubert's and other musicians' compositional work. For instance, Schubert's song cycle Die Winterreise (Winter Journey) is compared with song cycle Myrthen by Robert Schumann (1810-1956). The later work was described in due detail by Hart (2018). All pieces of music created by composers other than Schubert are categorized as 'Others.' This category includes songs by composers of late and early Romanticism: Franz Liszt (1811-1886), I.F. Stravinsky (1882-1971), Hector Berlioz (18031869), Georges Bizet (1838-1875), and Richard Wagner (1813-1883). A complete list of music compositions may be found at the end of this paper in Appendix 1.

\section{Materials and Methods}

The research methodology is presented by statistical analysis of qualitative and quantitative indicators of music, especially those that provide an opportunity to measure specific characteristics of sound (GEORGES, 2017). The method makes it possible to explore the common and distinctive features of composers' music in accordance with their manner of performance, as well as to analyze 
Statistical analysis of songs by composers of the Romantic era: A comparison... Linlin Gao • He Shen • Chang Liu

the large number of variations that occur during the performance of music by different composers (SUSADA et al., 2014). This study addresses the first five bars of the main theme. This approach only makes sense for simple musical forms (e.g., a song) as well as they have a simple structure and aimed to open the melody and give a strong feeling. For an optimal comparison, compositions of the same musical form (song) were selected, which date back to the Romantic era. The set of research material consists of the song cycles Die Winterreise by Franz Schubert and Myrthen by Robert Schumann (available at https://www.musicaneo.com/), and the pieces of music by Igor Stravinsky, Franz Liszt, Hector Berlioz, Georges Bizet, and Richard Wagner available at https://primanota. ru/ (see Appendix 1).

The study obtains $p$-values for each conditional parameter in order to prove findings reliable (to learn more about the role p-values in data processing, see WESTFALL et al. (1995). A p-value is a value that is determined randomly in the process of a statistical test used to analyze data and test the null hypothesis (LAKENS, 2021). The discrete probability function $F(x)$ is function that can take a discrete number of values (DAVOODI et al., 2021). It is calculated, which illustrates the probability for a certain value of a variable. This method is a good choice to objectively describe the work and identify the style of the composer as well as gives the opportunity to determine the specific features of composer 's style of singing. In addition, the study finds differences between the arrays of data. A more detailed description of statistical methods and their uses may be found in papers by MANDEL (2012) and FERREIRA (2011).

In this study, a piece of music is described by a set of integers of the discrete probability function $X=\left\{X_{i\}}{ }^{16}\right.$ in a manner similar to one used in RYDÉN (2020). Dependencies between the first two variables are plotted in accordance with ANSCOMBE (1973). Here, however, the study analyzes passages from compositions that have a constant pattern to simplify the calculation.

The integer $\times 3$, the number of pitch classes in RYDÉN (2020), represents another feature: 
Statistical analysis of songs by composers of the Romantic era: A comparison...

Linlin Gao • He Shen • Chang Liu

$\mathrm{x} 1$ - the passage length, expressed in the number of notes;

$x 2$ - the compass, measured in semitones;

x3 - the number of repeating notes;

x4 - the initial interval, measured in semitones;

$x 5$ - the number of non-repeating intervals;

x6 - the biggest interval; measured in semitones.

Noted that a conditional quantity $x 1$ gives no clue about the tempo of the music composition. At first glance, there is a certain correlation between the number of notes in a single passage and the overall tempo (the more notes, the faster the tempo, and vice versa). However, the element such as meter is also impactive. So far, music written in 2/4 time is performed more slowly as compared to music written in $4 / 4$ time.

Length, $x 1$.

Although it seems objective, this variable varies in terms of value depending on the musical form. Therefore, the research on songs only involves passages from the main theme (without trills, grace notes and other ornaments). Compositions that are exclusively instrumental, especially polyphonic, sometimes have a hard-to-identify theme (BAKULINA, 2012). Furthermore, similar notes tied by legato are counted as one note.

Compositions by Franz Schubert stand out with the greatest length and the meter could be the reason why. The shortest passages were found in the works by Schuman but they do not differ much in length from Schubert's. The maximum length is 33 tones (The Stormy Morning, Franz Schubert), whereas the minimum length is 10 tones (Lied Der Braut, Robert Schumann; The Pike, Igor Stravinsky; and Dreams, Richard Wagner).

Compass, $x 2$.

This variable shows the number of semitones (distance) between the highest and lowest notes in a given passage. Hereinafter, a semitone is taken as a unit of measurement in 
Statistical analysis of songs by composers of the Romantic era: A comparison... Linlin Gao • He Shen • Chang Liu

order to obtain integer non-negative data that is more convenient to process. Although the Schubert's passages have more notes, the range was found to be greater in Schumann's songs and this difference was significant. The maximum range is 17 semitones (Wasserfluth and Der greise Kopf, Franz Schubert; Senta's ballad from The Flying Dutchman, Richard Wagner), whereas the minimum range is 3 semitones (Der Wegweiser, Franz Schubert; Comment, disaientils, Franz Liszt).

\section{Number of reps, $x 3$.}

Repetition is characteristic to songs, regardless of their style and time of origin. For this reason, repetition of notes was included into the research. The number of reps is approximately the same in Schubert's and Schumann works. The maximum number of repeating notes is 12 (Hochländisches Wiegenlied, Robert Schumann), whereas the minimum number is 2 (Dreams, Richard Wagner).

\section{Initial interval, $x_{4}$}

This variable represents the distance between the first and second notes. Songs normally have roots ( 0 semitones), skips and leaps: minor and major thirds ( 3 and 4 semitones, respectively), perfect and augmented fourth ( 5 and 6 semitones), perfect and augmented octaves (12 and 13 semitones). Less often, you may encounter intervals that are greater than an octave ( $>13$ semitones) or intermediate options.

The maximum initial interval is 12 semitones (Weit, weit, Robert Schumann), whereas the minimum initial interval is 0 semitones (all compositions). The frequency of minimum intervals, however, varies depending on the composition. For instance, the use of roots is more frequent in Schubert's work than in Schumann's. In the pieces of music from the category Others, the minimum intervals are even less frequent. Hence, Igor Stravinsky and Richard Wagner had no use of roots in their work.

Unique Intervals, $x 5$.

The number of unique intervals in the work varies. There is no strong dependence upon the category but the most frequent 
Statistical analysis of songs by composers of the Romantic era: A comparison...

Linlin Gao • He Shen • Chang Liu

intervals are roots, minor and major seconds ( 1 and 2 semitones). They can be found in almost any song. Compositions by Franz Schubert are richer in skips and leaps than those by Robert Schumann. The maximum number of unique intervals is 9 (Schmerzen, Richard Wagner), whereas the minimum number is 2 (Weit, weit, Robert Schumann). The interval of root does not count as unique because it may be found in all compositions.

Max interval, $x 6$.

The maximum observed interval outcomes may be less than 5 semitones (small), more than 10 semitones (large), and range from 5 to 10 semitones (intermediate). These maximum intervals of 15 semitones are more frequent in Schubert's compositions than in the works by Schuman. The number of maximum intervals is 15 (Gute Nacht, Franz Schubert), whereas the minimum number is 3 (Der Wegweiser, Franz Schubert; Master Portly, Igor Stravinsky).

\section{Data processing}

Data processing was carried out with MatLab, and all histograms and tables were built in Excel 2016. Some works will not receive a detailed description given the trivial nature of findings. In assessing statistical significance, the significant level was chosen to be 5\% (0.05) as well as it 's standard indicator in general (PÉREZ and PERICCHI, 2014). Thus, all p-values of less than or equal to 0.05 may be considered reliable and highly accurate. P-values were found with fixed (n-1) and $x 2$, where $(\mathrm{n}-1)$ is the number of degrees of freedom, and $x 2$ is obtained by the following formula that represents the indicator of differences in indicators between observations and expectations. The formula also is represented by $\Theta$ - observations; e - expectations, expressed as an algebraic mean:

The number of observed episodes (the number of music compositions per category) is 20 . To simplify the calculations, the 
Statistical analysis of songs by composers of the Romantic era: A comparison...

Linlin Gao • He Shen • Chang Liu

number of degrees of freedom was measured as a difference between the maximum and minimum quantities observed to identify the average indicator of the average number of observed episodes:

\section{Limitations}

This study uses a simplified calculation procedure, which can lead to biased results that can be explained, for example, by specifics of music, inaccuracies during its measurement according to different indicators or peculiarities of the composer 's style of performing a certain composition.

\section{Results}

All works under study were considered separate categories of Schubert, Schumann, and Others. The results were arranged as tables with the first column showing the numbers of works that match those in the full list of studied compositions (see Appendix 1). The remaining columns contain information about the corresponding integers. Table 1 represents the results of the determination of musical parameters of Schubert's songs. They show different indicators that depends on the song and its features. The Table 2 represents the indicators of musical parameters of Schumann's songs and they also are different. The similar characteristic of these two composers is different indicators that cannot be grouped according to some features. The indicators of other composers are represented in the Table 3 and are also determined by different indicators. 
Statistical analysis of songs by composers of the Romantic era: A comparison... Linlin Gao • He Shen · Chang Liu

Table 1 - Quantification data in the category Schubert

\begin{tabular}{|l|l|l|l|l|l|l|}
\hline Composition & $\mathrm{x} 1$ & $\mathrm{x} 2$ & $\mathrm{x3}$ & $\mathrm{x} 4$ & $\mathrm{x} 5$ & $\mathrm{x} 6$ \\
\hline 1 & 17 & 15 & 5 & 1 & 7 & 15 \\
\hline 2 & 23 & 13 & 5 & 9 & 8 & 8 \\
\hline 3 & 16 & 7 & 6 & 0 & 4 & 12 \\
\hline 4 & 15 & 8 & 6 & 0 & 5 & 5 \\
\hline 5 & 15 & 7 & 6 & 0 & 4 & 4 \\
\hline 6 & 23 & 17 & 4 & 3 & 8 & 7 \\
\hline 7 & 18 & 7 & 6 & 0 & 5 & 12 \\
\hline 8 & 24 & 14 & 4 & 0 & 4 & 4 \\
\hline 9 & 20 & 12 & 7 & 0 & 6 & 8 \\
\hline 10 & 16 & 12 & 4 & 0 & 6 & 12 \\
\hline 11 & 17 & 14 & 4 & 0 & 7 & 9 \\
\hline 12 & 19 & 12 & 9 & 0 & 4 & 12 \\
\hline 13 & 15 & 9 & 6 & 0 & 5 & 5 \\
\hline 14 & 18 & 17 & 3 & 0 & 6 & 12 \\
\hline 15 & 18 & 12 & 3 & 1 & 6 & 5 \\
\hline 16 & 19 & 8 & 5 & 3 & 4 & 4 \\
\hline 17 & 23 & 10 & 7 & 0 & 4 & 10 \\
\hline 18 & 33 & 16 & 4 & 0 & 7 & 11 \\
\hline 19 & 11 & 9 & 3 & 0 & 5 & 5 \\
\hline 20 & 15 & 3 & 7 & 2 & 3 & 3 \\
\hline
\end{tabular}

Source: the authors.

Table 2 - Quantification data in the category Schumann

\begin{tabular}{|l|l|l|l|l|l|l|}
\hline Composition & $x 1$ & $x 2$ & $x 3$ & $x 4$ & $x 5$ & $x 6$ \\
\hline 1 & 23 & 14 & 7 & 0 & 7 & 9 \\
\hline 2 & 14 & 7 & 6 & 2 & 5 & 5 \\
\hline 3 & 17 & 5 & 7 & 0 & 4 & 5 \\
\hline 4 & 11 & 7 & 3 & 4 & 5 & 7 \\
\hline 5 & 13 & 7 & 7 & 0 & 4 & 7 \\
\hline 6 & 20 & 10 & 4 & 5 & 4 & 10 \\
\hline 7 & 14 & 12 & 4 & 0 & 6 & 5 \\
\hline 8 & 20 & 12 & 6 & 5 & 5 & 5 \\
\hline 9 & 22 & 10 & 5 & 0 & 6 & 5 \\
\hline 10 & 18 & 7 & 9 & 0 & 3 & 5 \\
\hline 11 & 11 & 9 & 4 & 5 & 5 & 7 \\
\hline 12 & 10 & 10 & 3 & 0 & 5 & 5 \\
\hline 13 & 13 & 10 & 4 & 0 & 5 & 4 \\
\hline 14 & 30 & 10 & 12 & 0 & 4 & 5 \\
\hline
\end{tabular}


Statistical analysis of songs by composers of the Romantic era: A comparison...

Linlin Gao · He Shen · Chang Liu

\begin{tabular}{|l|l|l|l|l|l|l|}
\hline 15 & 14 & 9 & 3 & 1 & 7 & 7 \\
\hline 16 & 23 & 9 & 8 & 0 & 7 & 5 \\
\hline 17 & 10 & 8 & 4 & 2 & 3 & 5 \\
\hline 18 & 14 & 8 & 4 & 0 & 4 & 8 \\
\hline 19 & 12 & 10 & 5 & 1 & 2 & 7 \\
\hline 20 & 18 & 14 & 5 & 12 & 5 & 12 \\
\hline
\end{tabular}

Source: the authors.

Table 3 - Quantification data in the category Others

\begin{tabular}{|c|c|c|c|c|c|c|}
\hline Composition & x1 & $x 2$ & x3 & $x 4$ & $\times 5$ & $x 6$ \\
\hline 1 & 22 & 5 & 5 & 3 & 5 & 4 \\
\hline 2 & 16 & 4 & 8 & 2 & 5 & 4 \\
\hline 3 & 10 & 7 & 4 & 7 & 4 & 7 \\
\hline 4 & 16 & 7 & 9 & 0 & 4 & 3 \\
\hline 5 & 19 & 8 & 8 & 0 & 5 & 4 \\
\hline 6 & 12 & 13 & 3 & 1 & 7 & 12 \\
\hline 7 & 11 & 3 & 7 & 0 & 3 & 3 \\
\hline 8 & 12 & 15 & 7 & 0 & 6 & 7 \\
\hline 9 & 11 & 14 & 8 & 9 & 4 & 9 \\
\hline 10 & 18 & 9 & 4 & 2 & 5 & 8 \\
\hline 11 & 24 & 6 & 7 & 0 & 4 & 5 \\
\hline 12 & 30 & 11 & 5 & 0 & 7 & 8 \\
\hline 13 & 24 & 12 & 11 & 5 & 7 & 5 \\
\hline 14 & 28 & 16 & 5 & 5 & 9 & 5 \\
\hline 15 & 14 & 10 & 5 & 0 & 5 & 5 \\
\hline 16 & 22 & 17 & 4 & 4 & 8 & 12 \\
\hline 17 & 23 & 9 & 9 & 0 & 5 & 6 \\
\hline 18 & 29 & 14 & 5 & 2 & 6 & 8 \\
\hline 19 & 10 & 9 & 2 & 9 & 4 & 9 \\
\hline 20 & 15 & 16 & 7 & 5 & 4 & 12 \\
\hline
\end{tabular}

Source: the authors.

The following histograms are based on data from the Tables 1-3 and showcase the probability for a certain value of each variable (Figures 1-3). 
Statistical analysis of songs by composers of the Romantic era: A comparison... Linlin Gao · He Shen · Chang Liu

Figure 1 - Histogram of quantities $\times 1 \ldots \times 2$ in the category Schubert

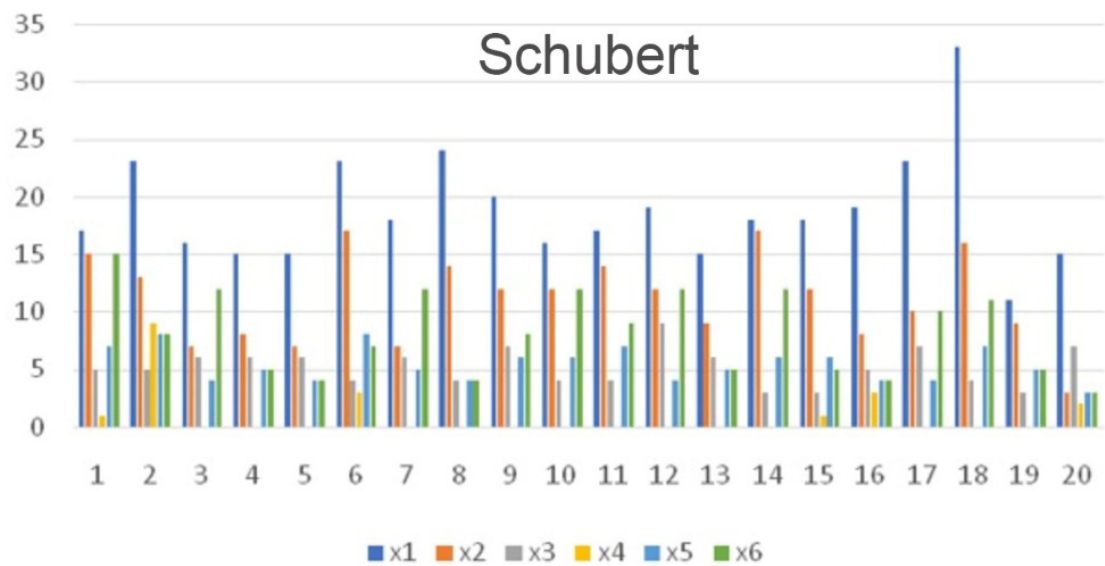

Source: the authors.

Figure 2 - Histogram of quantities $\times 1 \ldots \times 2$ in the category Schumann

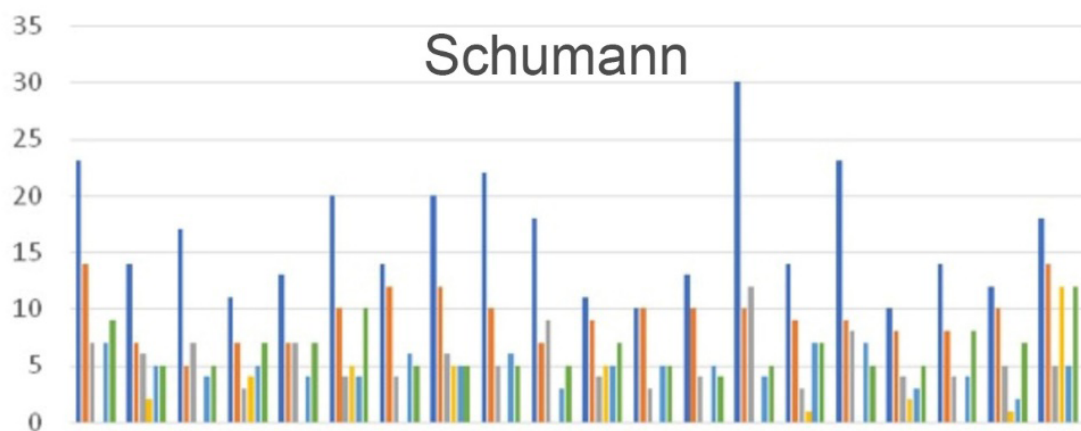

$\begin{array}{llllllllllllllllllll}1 & 2 & 3 & 4 & 5 & 6 & 7 & 8 & 9 & 10 & 11 & 12 & 13 & 14 & 15 & 16 & 17 & 18 & 19 & 20\end{array}$

$\Xi \times 1=\times 2 \equiv \times 3=\times 4 \equiv \times 5 \equiv \times 6$

Source: the authors.

Figure 3 - Histogram of quantities $\times 1 \ldots \times 2$ in the category Others

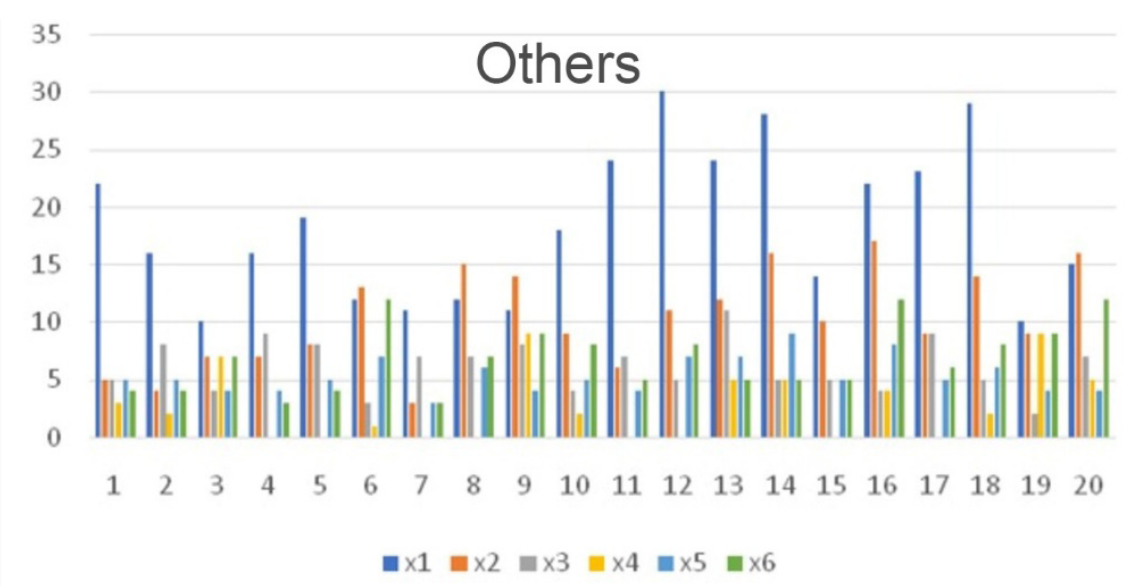

Source: the authors. 
Statistical analysis of songs by composers of the Romantic era: A comparison...

Linlin Gao • He Shen • Chang Liu

Information about the significance of features under consideration is presented in Tables 4-6. Table 4 represents the indicators of $p$-value of Schubert and show that they are varies between the 0.001-1 p. At the same time the $p$-values of Schumann very between 0.025-1 p (see Table 5). The indicators of $p$-values of others are characterized by the parameters varied between 0-1. As results show the highest indicator is $1 \mathrm{p}$ and presented in the songs of all composers as well as the lowest indicator is $0 \mathrm{p}$ and presented in the songs of the other composers.

\section{Table 4 - P-values of features in the category Schubert}

\begin{tabular}{|c|c|c|c|}
\hline \multicolumn{4}{|l|}{$\times 1$} \\
\hline$N$ & $<x>$ & $x^{2}$ & $p$ \\
\hline 22 & 18,75 & 22.70667 & 0.01 \\
\hline \multicolumn{4}{|l|}{$\times 2$} \\
\hline $\mathrm{N}$ & $<x>$ & $x^{2}$ & $p$ \\
\hline 14 & 11.1 & 25.02703 & 0.001 \\
\hline \multicolumn{4}{|l|}{ x3 } \\
\hline $\mathrm{N}$ & $<x>$ & $x^{2}$ & $p$ \\
\hline 6 & 5.2 & 9.461538 & 0.025 \\
\hline \multicolumn{4}{|l|}{$\times 4$} \\
\hline $\mathrm{N}$ & $<x>$ & $x^{2}$ & $p$ \\
\hline 4 & 0.95 & 91.52632 & 1 \\
\hline \multicolumn{4}{|l|}{$\times 5$} \\
\hline $\mathrm{N}$ & $<x>$ & $x^{2}$ & $p$ \\
\hline 5 & 5.4 & 7.555556 & 0.025 \\
\hline \multicolumn{4}{|l|}{$x 6$} \\
\hline $\mathrm{N}$ & $<x>$ & $x^{2}$ & $p$ \\
\hline 12 & 8.15 & 30.98773 & 0.001 \\
\hline
\end{tabular}

Note: blue highlights indicate that the measurement error is either very small or very large (this applies to other tables as well).

Source: the authors 
Statistical analysis of songs by composers of the Romantic era: A comparison... Linlin Gao · He Shen · Chang Liu

Table 5 - P-values of features in the category Schumann

\begin{tabular}{|llll|}
\hline$x_{1}$ & & & \\
\hline$N$ & $\langle x\rangle$ & $x 2$ & $p$ \\
\hline 20 & 16.35 & 33.06116 & 0.05 \\
\hline$x 2$ & & & \\
\hline$N$ & $<x>$ & $x 2$ & $p$ \\
\hline 9 & 9.4 & 11.14894 & 0.1 \\
\hline$x 3$ & & & \\
\hline$N$ & $<x>$ & $x 2$ & $P$ \\
\hline 9 & 5.5 & 18.36364 & 0.025 \\
\hline$x 4$ & & & \\
\hline$n$ & $<x>$ & $x 2$ & $p$ \\
\hline 12 & 1.85 & 95.43243 & 1 \\
\hline$x 5$ & & & $p$ \\
\hline$n$ & $<x>$ & $x 2$ & 0.2 \\
\hline 4 & 4.8 & 7.333333 & \\
\hline$x 6$ & & & 0.2 \\
\hline$n$ & $<x>$ & $x 2$ & \\
\hline 8 & 6.4 & 12.625 & \\
\hline
\end{tabular}

Source: the authors.

Table 6 - P-values of features in the category Others

\begin{tabular}{|llll|}
\hline$x 1$ & & & \\
\hline$n$ & $<x>$ & $x 2$ & $p$ \\
20 & 18.3 & 45.16438 & 0 \\
\hline$x 2$ & & & \\
\hline$n$ & $<x>$ & $x 2$ & $p$ \\
14 & 10.25 & 33.18447 & 0 \\
\hline$x 3$ & & & \\
\hline$n$ & $<x>$ & $x 2$ & $p$ \\
9 & 6.15 & 16.34959 & 0.05 \\
\hline$x 4$ & & & \\
\hline$n$ & $<x>$ & $x 2$ & $p$ \\
9 & 2.7 & 66 & 1 \\
\hline$x 5$ & & & $p$ \\
\hline$n$ & $<x>$ & $x 2$ & 0.01 \\
\hline 5 & 5.35 & 14.05093 & \\
\hline$x 6$ & & & 0 \\
\hline$n$ & $<x>$ & $x 2$ & \\
\hline 9 & 6.8 & 30.50588 & \\
\hline
\end{tabular}

Source: the authors. 
Statistical analysis of songs by composers of the Romantic era: A comparison...

Linlin Gao • He Shen • Chang Liu

Knowing the p-values of each feature in all categories, the probability for a particular outcome in the research may be measured by finding a discrete distribution function. This may be either the function used in GUPTA et al. (2014) or any other from the broad range of choices. In this study, the distribution function in the first quarter plane has a stepwise form:

The distribution functions above relate the Schubert category. As can be seen, the distributions of different quantities weakly correlate with each other. The distributional data conclude the following probabilities: $x_{1}$ is likely to be in the range $(20 ; 23) ; x 2-$ in the range $(10 ; 12) ; x 3$ - in the region of $(3 ; 4), x 5$ - within $(10 ; 12)$, and $x 6$ is the most likely to be 12 . The variable $x 4$ is likely to be 0 . The $p$-value tends to 1 , which suggests an extremely low error rate.

Obtained results show the most possible values of studied parameters. Thus, the results can be applied in identifying missing notes, illustrating the most possible distribution of the studied values. Moreover, they can be helpful in case when authorship is suspect.

\section{Discussion}

The results of the study show the differences in the numerical data of musical conclusions according to the indicators of the different composers ' music. It 's determined that the indicators of Schubert, Schumann, and Others compositions according to the corresponding integers are different that can be explained by the specifics of the manner of performing songs, the musical accompaniment of a certain composer, the quantitative and qualitative indicators of the sound created as a result. The p-values of each feature in all categories of composers also have some similar indicators but in general, the indicators fluctuate within the average values and do not differ significantly. 
Statistical analysis of songs by composers of the Romantic era: A comparison... Linlin Gao • He Shen • Chang Liu

Despite a strong historical research on the music life of Franz Schubert (BLACK, 2003; WOLLENBERG, 2011), his music compositions were little studied statistically or at least mathematically. Furthermore, songs are in principle rarely in terms of a mathematical perspective. Normally, math related research is concerned with the instrumental works of the late Baroque and Classicism, for they are well balanced and harmonic. Music compositions by Franz Schubert, the Die Winterreise cycle especially (BAUMANN and LUETGERT, 1982) received a detailed analysis as an object of musicology (MAZZOLA et al., 2016). MUXFELDT (2012) compares the work by Franz Schubert and Robert Schumann in a historical and musical review.

The current study modified the research method offered by RYDÉN (2020) to analyze small five-bar passages, rather than the whole piece. Note that this modification only relates to the simple musical forms such as a song, whilst forms that are more complex cannot be assessed with it due to a higher risk of bias. Even in the song-based research, this risk is present. Such a problem can be solved if one considers the neglected as data that is missing and makes certain assumptions (LITTLE and RUBIN, 2019). Besides methods of statistical analysis, there are many other mathematical approaches and theories in the music research: the magic square matrix used by the famous British composer Sir Peter Maxwell Davis (ROBERTS, 2016), computational methods for aligning and evaluating the transcription of piano music (WANG, 2017), tabular bell modeling (BÜHLER, 2019; OLIVER and ARSIE, 2019), and so on. Music and mathematics can overlap to generate new ideas in architecture (RAO, 2014). For example, Iannis Xenakis, the composer, built a collaborative relationship with Le Corbusier, the architect, to create the Philips Pavilion (STERKEN, 2007). The union of mathematics and music is not less fruitful in education and psychology. Music, for example, has a positive impact on the student's performance in STEM (science, technology, engineering and mathematics) classes (SHAW, 2003), their short-term memory, and cognitive abilities (CHRISTOPHER and SHELTON, 2017). 
Statistical analysis of songs by composers of the Romantic era: A comparison...

Linlin Gao • He Shen • Chang Liu

\section{Conclusions}

This study found discrete distributions and p-values of specific integrates, and examined statistical relationships between these for Franz Schubert's song cycle Die Winterreise, for compositions by Robert Schumann and by other composers of the Romantic era. The study revealed that the work of Franz Schubert had longer passages and greater ranges $x_{2}$ as compared to works by other composers. Besides, he made the use of roots in this work and had more unique and maximum intervals than others. Somewhat surprisingly, the number of note repetitions was found to be approximately the same as that in other two categories. Obtained results could be helpful

All works were not considered as whole pieces but their partial analysis saves time and simplifies calculations. The future research will be based on a deeper and objective analysis of the main theme (and all choral sections if the composition is choral). Apart from this excerpt, the accompaniment should be considered as a separate category. Furthermore, some additional features may be addressed such as pitch classes, harmonic implications, and rhythmic features. The practical significance of the study is explained by the opportunity to use the results in finding objective criteria for describing his work in comparison with the works of other composers. They also are useful for restoring musical notations, analyzing and classifying works of unknown authorship. The prospects for further research are determined by the use of proposed model for the studying and analyzing the songs of composers not only the Romantic era, but also other periods.

\section{References}

ANSCOMBE, Frank J. Graphs in statistic analysis. The American

Statistician, v. 27, n. 1, p. 17-21, 1973. 
Statistical analysis of songs by composers of the Romantic era: A comparison... Linlin Gao • He Shen • Chang Liu

BAKULINA, Olga. The loosening role of polyphony: texture and formal functions in Mozart's "Haydn" quartets. Intersections: Canadian Journal of Music/Intersections: revue canadienne de musique, v. 32, n. 1-2, p. 7-42, 2012.

BAUMANN, Cecilia C., LUETGERT Mike J. “Die Winterreise": the secret of the cycle's appeal. Mosaic: A Journal for the Interdisciplinary Study of Literature v. 15, n. 1, p. 41-52, 1982.

BLACK, Leo. Franz Schubert: music and belief. Woudbridge: Boydell Press, p. 226, 2003.

BÜHLER, Walte. Consonance based interval systems and their matrices: Leibniz's harmonic equations. Journal of Mathematics and Music, v. 13, n. 1, p. 42-59, 2019.

BURKHOLDER, J. Peter, GROUT, Donald Jay, PALISCA, Claude V. A History of Western Music: Tenth International Student Edition. New York: WW Norton \& Company, p. 226, 2019.

CASALIGGI, Carmen, FERMANIS, Porscha. Romanticism: A Literary and Cultural History. London: Routledge, p. 282, 2016.

CHRISTOPHER, Eddie A., SHELTON, Jill Talley. Individual differences in working memory predict the effect of music on student performance. Journal of Applied Research in Memory and Cognition, v. 6, n. 2, p. 167-173, 2017.

CORRÊA, Débora C., AP RODRIGUES, Francisco. A survey on symbolic data-based music genre classification. Expert Systems with Applications, v. 60, p. 190-210, 2016.

DALLA BELLA, Simone, PERETZ, Isabelle. Differentiation of classical music requires little learning but rhythm. Cognition, v. 96, n. 2, p. 6578, 2005.

DAVOODI, Arash Gholami, CHANG, Sean, YOO, Hyun Gon, BAWEJA, Anubhav, MONGIA, Mihir, MOHIMANI, Hosein. ForestDSH: a universal hash design for discrete probability distributions. Data Mining and Knowledge Discovery, v. 35, p. 748-795, 2021.

EDELSON, R. Jill, JOHNSON, Gretchen. Music makes math meaningful. Childhood Education, v. 80, n. 2, p. 65-70, 2003. 
Statistical analysis of songs by composers of the Romantic era: A comparison... Linlin Gao • He Shen • Chang Liu

ELAINE, Chew, GERARD, Assayag, BL, Smith Jordan. Mathemusical Conversations: Mathematics and Computation in Music Performance and Composition (Vol. 32). Singapore: World Scientific, p. 314, 2016.

FERREIRA, Daniel Furtado Sisvar: a computer statistical analysis system. Ciência e Agrotecnologia, v. 35, n. 6, p. 1039-1042, 2011. FOWLER, Michael D. An analysis of pitch-class segmentation in John Cage's Ryoanji for oboe using morphological image analysis and formal concept analysis. Journal of Mathematics and Music, v. 14, n. 1, p. 21 47, 2020.

GEORGES, Patrick. Western classical music development: a statistical analysis of composers similarity, differentiation and evolution.

Scientometrics, v. 112, p. 21-53, 2017.

GOMEZ, Florian, LORIMER, Tom, STOOP, Ruedi. Complex networks of harmonic structure in classical music. In: International Conference on Nonlinear Dynamics of Electronic Systems. Cham: Springer, p. 262269, 2014.

GRIER, James. The critical editing of music: history, method, and practice. Cambridge: Cambridge University Press, p. 284, 1996.

GUPTA, Ramesh C., SIM, Siong Z., ONG SH. Analysis of discrete data by Conway-Maxwell Poisson distribution. AStA Advances in Statistical Analysis, v. 98, n. 4, p. 327-343, 2014.

HART, Kelly. Text Setting and Harmony in Schumann's Myrthen Op. 25: Pedagogical Applications in the Theory Curriculum. [Master Thesis] Greenville: East Carolina University, p. 135, 2018. HONOUR, Hugh. Romanticism. London: Routledge, 2018. 415 p. LAKENS, Daniël. The practical alternative to the $p$ value is the correctly used $p$ value. Perspectives on Psychological Science, v. 16, n. 3, p. 639-648, 2021.

LITTLE, Roderick JA, RUBIN, Donald B. Statistical analysis with missing data (Vol. 793). New York: John Wiley \& Sons, p. 464, 2019. 
Statistical analysis of songs by composers of the Romantic era: A comparison... Linlin Gao • He Shen • Chang Liu

LIU, Xiao Fan, CHI, Tse K., SMALL, Michael. Complex network structure of musical compositions: Algorithmic generation of appealing music. Physica A: Statistical Mechanics and its Applications, v. 389, n. 1, p. 126-132, 2010.

MANDEL, John. The statistical analysis of experimental data. North Chelmsford: Courier Corporation, p. 432, 2012.

MARTORELL, Agustín, GÓMEZ, Emilia. Hierarchical multi-scale set-class analysis. Journal of Mathematics and Music, v. 9, n. 1, p. 95-108, 2015. MAZZOLA, Guerino, MANNONE, Maria, PANG, Yan. Cool math for hot music. New York: Springer International Publishing Switzerland, p. 323, 2016.

MCKAY, Elizabeth N. Franz Schubert: A Biography. The Opera Quarterly, v. 55, n. 1, p. 105-108, 1998.

MUXFELDT, Krisitna. Vanishing Sensibilities: Schubert, Beethoven, Schumann. Oxford: Oxford University Press, 2012. 272 p.

NG, Samuel. Phrase rhythm as form in classical instrumental music. Music Theory Spectrum, v. 34, n. 1, p. 51-77, 2012.

OLIVER, Douglas L., ARSIE, Alessandro. Effects of weighting the ends of a tubular bell on modular frequencies. Journal of Mathematics and Music, v. 13, n. 1, p. 27-41, 2019.

PÉREZ, María-Eglée, PERICCHI, Luis Raúl. Changing statistical significance with the amount of information: The adaptive a significance level. Statistics \& Probability Letters, v. 85, p. 20-24, 2014.

POPOFF, Alexandre, MORENO, Andreatta, EHRESMANN, Andrée. Relational poly-Klumpenhouwer networks for transformational and voice-leading analysis. Journal of Mathematics and Music, v. 12, n. 1, p. 35-55, 2018.

RAO, Rajshekhar. Music in architecture too. Architecture-Time Space and People, v. 1, p. 32-35, 2014.

REN, Yang, KOOPS, Hendrik Vincent, BOUNTOURIDIS, Dimitrios, VOLK, Anna, SWIERSTRA, Wouter, VELTKAMP, Remco. Feature analysis of repeated patterns in dutch folk songs using principal component 
Statistical analysis of songs by composers of the Romantic era: A comparison...

Linlin Gao • He Shen • Chang Liu

analysis. In: Proceedings of the 8th International Workshop on Folk Music Analysis (FMA2018). Thessaloniki: Aristotle University of Thessaloniki, p. 86-88, 2018.

REYNOLDS, Roger. Form and method: Composing music: The Rothschild essays. London: Routledge. p. 256, 2013.

ROBERTS, Gareth E. From music to mathematics: exploring the connections. Baltimore: JHU Press. p. 320, 2016.

RYDÉN, Jesper. On features of fugue subjects. A comparison of JS Bach and later composers. Journal of Mathematics and Music, v. 14, n. 1, p. 1-20, 2020.

SHAFER, Jennifer, SULTON, Randall. The two-part and three-part inventions of Bach: a mathematical analysis. [Honors project] Marshall: East Texas Baptist University, p. 168, 2010.

SHAW, Gordon L. Keeping Mozart in mind. New York: Elsevier, p. 411, 2003.

SMITHER, Howard E. A history of the Oratorio: Vol. 4: The Oratorio in the nineteenth and twentieth centuries. Chapel Hill: UNC Press Books. p. 856, 2012.

STERKEN, Sven. Music as an art of space: interactions between music and architecture in the work of Iannis Xenakis. Ressonance: Essays on Intersection of Music and Arquitecture, v. 1, p. 21-51, 2007.

SUSADA, Jesse Sagayno, AVENIDO, Jessica, BARABAT, Efren O. Classicalromantic compositions: A musical variation analysis. Recoletos

Multidisciplinary Research Journal, v. 1, n. 2, p. 109-114, 2014.

WANG, Siying. Computational Methods for the Alignment and Score-Informed Transcription of Piano Music. [Doctoral dissertation] London: Queen Mary University of London, p. 151, 2017.

WESTFALL, Peter H., YOUNG, Stanley S. ResamplingBased Multiple Testing. Examples and Methods for $p$-Value Adjustment. Computational Statistics and Data Analysis, v. 20, n. 2, p. 235-238, 1995. 
Statistical analysis of songs by composers of the Romantic era: A comparison...

Linlin Gao • He Shen • Chang Liu

WOLLENBERG, Susan. Schubert's Fingerprints: Studies in the

Instrumental Works. Farnham: Ashgate Publishing, Ltd, p. 317, 2011.

\section{Appendix 1}

Musical compositions from the song cycle Die Winterreise by Franz Schubert depicted in Table 1:

1. 'Gute Nacht';

2. 'Die Wetterfahne';

3. 'Gefror'ne Thränen';

4. 'Erstarrung';

5. 'Der Lindenbaum';

6. 'Wasserfluth';

7. 'Auf dem Flusse';

8. 'Rückblick';

9. 'Irrlicht';

10. 'Rast';

11. 'Frühlingstraum';

12.'Einsamkeit';

13. 'Die Post';

14. 'Der greise Kopf';

15.'Die Krähe';

16. 'Letzte Hoffnung';

17.'Im Dorfe';

18. 'Der stürmische Morgen';

19.'Täuschung';

20. 'Der Wegweiser'. 
Statistical analysis of songs by composers of the Romantic era: A comparison...

Linlin Gao • He Shen • Chang Liu

Musical compositions from the song cycle Myrthen by Robert Schumann depicted in Table 2:

1. 'Widmung';

2. 'Laissez-moi gaiement monter en selle';

3. 'Der Nussbaum'

4. 'Jemand';

5. 'Lieder \#1';

6. 'Lieder \#2';

7. 'Die Lotosblume';

8. 'Talismane';

9. 'Lied der Suleika';

10.'Die Hochländer-Wittwe';

11.'Lied der Braut \#1';

12.'Lied der Braut \#2';

13.'Hochländers Abschied';

14.'Hochländisches Wiegenlied';

15.'Aus den hebräischenGesänger';

16.'Räthsel';

17.'Zwei Venetianische Lieder \#1';

18. 'Zwei Venetianische Lieder \#2';

19.'Hauptmann `s Weid';

20. 'Weit, weit'.

Musical compositions by other composers depicted in Table 3:

'In Our Savior's Parish at Chigasi' (a.k.a 'On Saints' Day”) from Four Russian Peasant Songs by Igor Stravinsky. Passage starts from the second bar. The first two bars are written in 2/4 time, followed 
Statistical analysis of songs by composers of the Romantic era: A comparison...

Linlin Gao • He Shen • Chang Liu

by a bar in 3/8 time, and by bars in 2/4 time. Passage score, soprano; D major.

1. 'Ovsen' from Four Russian Peasant Songs by Igor Stravinsky. Passage starts from the third bar. Passage score, soprano; meter, 3/8; D major.

2. 'The Pike' from Four Russian Peasant Songs by lgor Stravinsky. Passage starts from the second bar. Passage score, soprano. The first bar is written in $3 / 4$ time, followed by two bars in $3 / 8$ time, one bar in 2/8 time, and five bars in 3/8 time. D major.

3. 'Master Portly' from Four Russian Peasant Songs by Igor Stravinsky. Passage starts from the second bar. The first two bars are written in $2 / 8$, followed by one bar in $3 / 8$ time, and bars in 2/4 time. D major.

4. 'In Liebeslust', Franz Liszt;

5. 'Wo weilt er?', Franz Liszt;

6. 'Comment, disaient-ils', Franz Liszt;

7. 'Les nuits d'été', Hector Berlioz;

8. 'd'Ophélie', Hector Berlioz;

9. 'Vieille chanson', Georges Bizet;

10. 'Les deux grenadiers', Richard Wagner. Passage starts from the forth bar. Meter, 4\4; tempo, fast; A minor.

11.'Dors, mon enfant', Richard Wagner. Ornaments in the first and the third bars are not taken into account. Meter, 918; tempo, slow; D minor.

12.'Der Rosa', Richard Wagner. Ornaments in the first and second bars as well as extensions in the forth bar are not taken into account. Meter, 9/8; tempo, fast; E major.

13.'L'attente', Richard Wagner. Passage starts from the fifth bar. Meter, 6/8; tempo, fast; D minor.

14.'Engel' from Fünf Gedichte von Mathilde Wesendonck, Richard Wagner. Passage starts from the third bar. Meter, 4/4; tempo, fast; C\# minor. 
Statistical analysis of songs by composers of the Romantic era: A comparison...

Linlin Gao • He Shen • Chang Liu

15.'Stehe Still' from Fünf Gedichte von Mathilde Wesendonck, Richard Wagner. Passage starts from the third bar. Meter, 6/8; tempo; lively; A minor.

16.'Im Treibhaus' from Fünf Gedichte von Mathilde Wesendonck, Richard Wagner. Passage starts from the sixth bar. The first two bars are written in 6/8 time, followed by bars in $9 / 8$ time. Tempo, slow; B minor.

17.'Schmerzen' from Fünf Gedichte von Mathilde Wesendonck, Richard Wagner. Passage starts from the third bar. Meter, 4/4; tempo, slow; C minor.

18.'Träume' from Fünf Gedichte von Mathilde Wesendonck, Richard Wagner. Passage starts from the 17th bar. Meter, 3/4; tempo; moderate; D minor.

19.'Ballade aus dem Fliegenden Holländer', Richard Wagner. Passage starts from the 11 th bar. Meter, 618; tempo, fast; G minor. Ornaments are not taken into account.

\section{Publisher}

Federal University of Goiás. School of Music and Performing Arts. Graduate Program in Music. Publication in the Portal of Periodicals UFG.

The ideas expressed in this article are the responsibility of their authors, and do not necessarily represent the opinion of the editors or the university. 